\title{
Bird predation on nest of a social wasp in Brazilian cerrado
}

\author{
Raimundo Paulo Barros Henriques and Alexandre Ramlo Torre Palma \\ Departamento de Ecologia, Universidade de Brasilia, C. P. 04457, CEP 70919-970, Brasíia, DF, Brazil. Fax: 55-61- \\ 273-471. E-mail: henriq@guarany.unb.br
}

Recibido 24-III-98. Corregido 2-VII-1998. Aceptado13-VII-1998

Key words: Apoica pallens, Brazil, curl-crested jay, Cyanocorax cristatellus, neotropical savanna.

Birds are rarely observed preying upon wasps' nests (Bertoni 1911, Rau 1941, Alvarez del Toro 1950, Skutch 1959, Windsor 1976). Many of the observations are recorded in tropical forest on nests of Polybia and Metapolybia. In this note we present the first observations on the predation by the curlcrested jay (Cyanocorax cristatellus) upon the nest of a social wasp (Apoica pallens) in cerrados of Central Brazil.

The observations were made in the Reserva Ecológica do Instituto Brasileiro de Geografia e Estatística, located at $15^{\circ} 57^{\prime} \mathrm{S}$ and $47^{\circ} 53^{\prime} \mathrm{w}, 16 \mathrm{~km} \mathrm{SW}$ of Brasília city (D.F.). This area is situated in the core of the cerrados region (the neotropical savanna). The climate is markedly seasonal, with a dry season between May and August. The average annual rainfall is $1456 \mathrm{~mm}$ and the mean annual temperature is $21.3^{\circ} \mathrm{C}$.

The wasp nest of $A$. pallens was located $2 \mathrm{~m}$ above ground, deep within the crown of a large shrub (Miconia ferruginata) in a area of closed woodland (cerradão). This physiognomy is a type of semideciduous forest within cerrados region, with trees 10 $14 \mathrm{~m}$ tall, $50-90 \%$ canopy cover and a poorly developed understory. In the cerrados region $A$. pallens is frequently found in woodland areas (Cerradão, Gallery forest, Dry forest) (Diniz \& Kitayama 1994; R. P. B. Henriques, personal observations). The hat- like nest of $A$. pallens, $15 \mathrm{~cm}$ in diameter and $6 \mathrm{~cm}$ in depth, had one cell layer and a few dozen adult wasps. In the cerrados this species occurs at a very low abundance $(<<1$ nest/ha) (Henriques et al. 1992, Diniz \& Kitayama 1994).

We watched predation at 11:30 a.m. on 16 June 1997, when three curl crested jays flew and vocalized around the srhub wich was surrounded by a cloud of adult wasps, approximately $5 \mathrm{~m}$ in diameter. After a few minutes two jays perched in nearby trees (10 $\mathrm{m})$ and the third $1.5 \mathrm{~m}$ from the nest. We were unable to observe whether the jays were stung during these activities. One hour later we returned to the site. The intensity of the wasps defensive swarming had diminished; several adults landed and stayed on understory vegetation but had not returned to the nest. Below the shrub we found nest parts scattered on the ground. Neither larvae nor pupae remained in the nest.

The observations we present here are consistent with the suggestion of Henriques et al. (1992) that nests of social wasps are attacked by vertebrates in cerrados. Windsor (1976) also believed that predation by birds on nests of social wasps is more prevalent in savannas. These observations suggest that predation by birds could play an important role in the dynamics of social wasp populations. 


\section{CUADRO}

Algunas moscas Bombyliidae y Tachinidae parasitoides de lepidópteros en Costa Rica

\begin{tabular}{|c|c|c|}
\hline Especie parasitoide & Especie hospedante & Especie vegetal \\
\hline \multicolumn{3}{|l|}{ Bombyliidae } \\
\hline Systropus sp. & $\begin{array}{l}\text { Acharia ophelians } \\
\text { Dyar (Limacodidae) }\end{array}$ & $\begin{array}{l}\text { Mangifera indica } \mathrm{L} . \\
\text { (Anacardiaceae) }\end{array}$ \\
\hline \multicolumn{3}{|l|}{ Tachinidae } \\
\hline Belvosia spp. & $\begin{array}{l}\text { Automeris sp. (Saturniidae) } \\
\text { Hylesia lineata Druce } \\
\text { (Saturniidae) }\end{array}$ & $\begin{array}{l}\text { Carica papaya L.(Caricaceae) } \\
\text { Psidium friedrichsthalianum } \\
\text { (Berg) Niedenzu (Myrtaceae) }\end{array}$ \\
\hline \multirow[t]{3}{*}{ Hyphantrophaga spp. } & $\begin{array}{l}\text { Chlosyne janais Drury } \\
\text { (Nymphalidae) }\end{array}$ & Acanthaceae \\
\hline & $\begin{array}{c}\text { Chlosyne lacinia Geyer } \\
\text { (Nymphalidae) }\end{array}$ & $\begin{array}{l}\text { Helianthus annus } \mathrm{L} \text {. } \\
\text { (Asteraceae) }\end{array}$ \\
\hline & $\begin{array}{c}\text { Pythonides hyacinthinus Mab. } \\
\text { (Hesperiidae) }\end{array}$ & $\begin{array}{c}\text { Persea americana Mille } \\
\text { (Lauraceae) }\end{array}$ \\
\hline $\begin{array}{l}\text { Patelloa sp. } \\
\text { Winthemia sp. }\end{array}$ & $\begin{array}{c}\text { Pythonides hyacinthinus } \\
\text { (Hesperiidae) }\end{array}$ & Persea americana Miller \\
\hline Phytomiptera sp. & $\begin{array}{l}\text { Keifferia lycopersicella } \\
\text { Walsingham (Gelechiidae) }\end{array}$ & $\begin{array}{l}\text { Lycopersicon esculentum } \\
\text { Millspaugh (Solanaceae) }\end{array}$ \\
\hline
\end{tabular}

\section{REFERENCIAS}

Adams, J.K.\& D. Yanega. 1991. The lepidopteran host of a neotropical Bombyliid fly (Lepidoptera: Limacodidae, Diptera: Bombyliidae). J. Kans. Entomol. Soc. 64: 443-444.

Janzen, D. H. 1995. The caterpillars and their parasitoids of a tropical dry forest. Tachinid Times Newsl. 8: 1-3
Mexzón, R.G. \& C.M. Chinchilla. 1996. Enemigos naturales de los artrópodos perjudiciales a la palma aceitera (Elaeis guineensis) en América Tropical. ASD Oil Palm Paper (Costa Rica) 13: 9-33.

Quezada, J.R. \& A. Rodríguez. 1989. Brote de larvas de Rothschildia orizaba (Lepidoptera: Satumiidac) en café, una experiencia en Manejo Integrado de Plagas. MIP 12: 21-32. 